Journal of Southeast Asian

\title{
Two Poems: My Interaction with Other SE Asian Communities, Struggle to Laotian Community
}

Prinston Pan

prinston.pan@gmail.com

Follow this and additional works at: https://docs.lib.purdue.edu/jsaaea

Part of the Bilingual, Multilingual, and Multicultural Education Commons

\section{Recommended Citation}

Pan, Prinston (2021) "Two Poems: My Interaction with Other SE Asian Communities, Struggle to Laotian Community," Journal of Southeast Asian American Education and Advancement. Vol. 16 : Iss. 1, Article 1. DOI: $10.7771 / 2153-8999.1225$

Available at: https://docs.lib.purdue.edu/jsaaea/vol16/iss1/1

This document has been made available through Purdue e-Pubs, a service of the Purdue University Libraries. Please contact epubs@purdue.edu for additional information.

This is an Open Access journal. This means that it uses a funding model that does not charge readers or their institutions for access. Readers may freely read, download, copy, distribute, print, search, or link to the full texts of articles. This journal is covered under the CC BY-NC-ND license. 


\title{
ISAAEA Journal of Southeast Asian American Education and Advancement
}

Vol. 16 Iss. 1 (2021)

WWW.JSAAEA.org

\section{Creative and Literary Works}

\section{Two Poems}

\author{
Prinston Pan
}

\section{$\underline{\text { My Interaction with other SE Asian Communities }}$}

The bell rings

The scorching sun out and about

Burning into the back of our necks

It's lunch time.

One brought banh,

The other brought Prahak,

I brought my laap

Together we bond through

One theme: underrepresentation

We teach each other

We learn from each other

So we can fight the same problems that we all have

We create communities at school

To invoke discussion

And bring forth new ideas

To help cure the illness that we all suffer from

We can't fix this on our own

We need to find others who are similar to us

The three boys with the same home-made lunches

We all seek equality and resources

The matter is how we work together to succeed

We are the next generation

We need to be the one to change

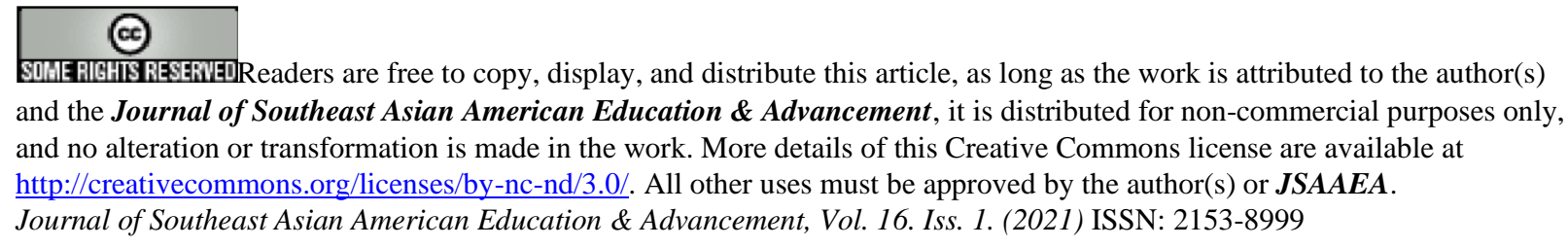


If we never work together things will stay the same

We must learn from the past to succeed in the future

\section{$\underline{\text { Struggle to Laotian community }}$}

The history of my people is beginning to fade

The elders are emotionally scarred

It hurts for them to relive the war

Or think "what would happen if we stayed?"

Yet this is something that our generation must work around

We must realize that we must be wholesome to get to the dark answers we seek

Direct questions will only drag us down

Little steps are the only way

We need to ask questions that bring fond memories

That lead into a deep dark hole

Where the answers are that you seek

The answers that you need to preserve the history of our people

About the Author

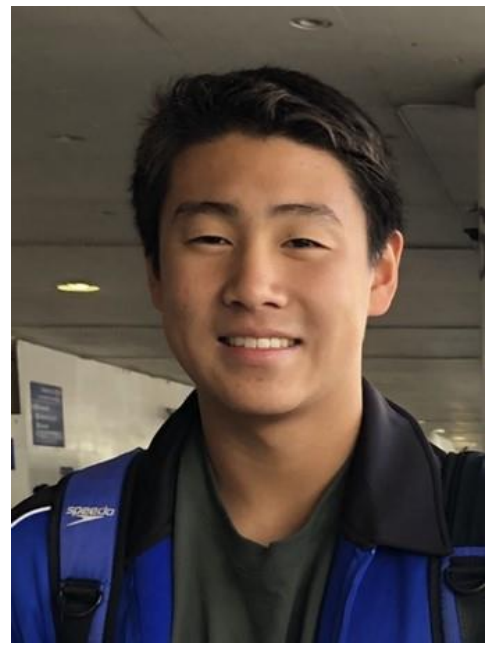

Prinston Pan was born in Kansas and is currently living in Southern California. Growing up he spent most of his summers in Kansas at his grandparents' Lao grocery store, where he interacted with many customers and learned about their lives in Laos. He is also the author of Kong's Adventure, a children's book about his grandfather's journey from Laos to America. 


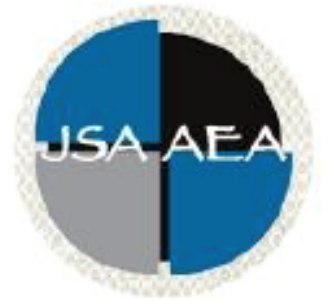

Vol.16 Iss.1 (2021)

\title{
Journal of Southeast Asian American Education and Advancement
}

\author{
WWW.JSAAEA.org
}

\section{Editor}

Dr. Wayne E. Wright

Purdue University

Associate Editors

Dr. Chhany Sak-Humphry

University of Hawaii at Manoa

Dr. Phitsamay Sychitkokhong Uy

University of Massachusetts, Lowell

\author{
Book Review Editor \\ Dr. Vichet Chhuon \\ University of Minnesota \\ Creative Works Editor \\ Bryan Thao Worra \\ Lao Assistance Center \\ Journal Manager \\ Chen Li \\ Jeffrey Sovan Wright \\ Purdue University
}

\section{Editorial Review Board}

\author{
Dr. Steve Arounsack \\ California State University, Stanislaus \\ Dr. Sovicheth Boun \\ Salem State University \\ Dr. Virak Chan \\ Purdue University \\ Dr. Loan Dao \\ University of Massachusetts Boston
}

\author{
Dr. Carl L. Bankston III \\ Tulane University \\ Dr. Phala Chea \\ Lowell Public Schools \\ Dr. George Chigas \\ University of Massachusetts, Lowell \\ Dr. Hien Duc Do \\ San Jose State University
}




\author{
Dr. Linh Dang \\ KIPP DC Headquarters \\ Dr. Sophal Ear \\ Occidental College \\ Dr. Vincent K. Her \\ University of Wisconsin, Eau Claire \\ Dr. Nancy H. Hornberger \\ University of Pennsylvania \\ Dr. Peter Tan Keo \\ New York University \\ Dr. Yvonne Kwan \\ San Jose State University \\ Dr. Ravy Lao \\ California State University, Los Angeles \\ Dr. Stacey Lee \\ University of Wisconsin, Madison \\ Dr. Jacqueline Mac \\ Northern Illinois University \\ Dr. Bic Ngo \\ University of Minnesota \\ Dr. Leakhena Nou \\ California State University, Long Beach \\ Dr. Mark Pfeifer \\ SUNY Institute of Technology \\ Dr. Loan T. Phan \\ University of New Hampshire \\ Dr. Karen Quintiliani \\ California State University, Long Beach \\ Dr. Angela Reyes \\ Hunter College \\ The City University of New York \\ Dr. Fay Shin \\ California State University, Long Beach \\ Dr. Christine Su \\ College of San Mateo \\ Dr. Alisia Tran \\ Arizona State University \\ Dr. Khatharya Um \\ University of California, Berkeley \\ Dr. Kim Tran \\ University of California, Los Angeles, \\ Glendale Community College \\ Dr. Molly Wiebe \\ The University of Texas at Austin \\ Dr. Changming Duan \\ University of Missouri-Kansas City \\ Dr. Sothy Eng \\ Lehigh University \\ Dr. Jeremy Hein \\ University of Wisconsin, Eau Claire \\ Dr. Peter Nien-Chu Kiang \\ University of Massachusetts, Boston \\ Dr. Kevin K. Kumashiro \\ University of Illinois, Chicago \\ Dr. Ha Lam \\ Independent Scholar \\ Dr. Jonathan H. X. Lee \\ San Francisco State University \\ Dr. Monirith Ly \\ Royal University of Phnom Penh \\ Dr. Sue Needham \\ California State University, Dominguez Hills \\ Dr. Max Niedzwiecki \\ Daylight Consulting Group \\ Dr. Clara Park \\ California State University, Northridge \\ Dr. Giang Pham \\ University of Massachusetts Amherst \\ Dr. Malaphone Phommasa \\ University of California Santa Barbara \\ Dr. Kalyani Rai \\ University of Wisconsin-Milwaukee \\ Dr. Cathy J. Schlund-Vials \\ University of Connecticut, Storrs \\ Dr. Nancy J. Smith-Hefner \\ Boston University \\ Dr. Yer J. Thao \\ Portland State University \\ Dr. Monica M. Trieu \\ Purdue University \\ Dr. Silvy Un \\ Saint Paul Public Schools \\ Dr. Linda Trinh Vo \\ University of California, Irvine \\ Dr. Varaxy Yi Borromeo \\ California State University, Fresno \\ Dr. Yang Sao Xiong \\ The University of Wisconsin-Madison

\section{Dr. Zha Blong Xiong} \\ University of Minnesota
}




\section{Doctoral Student Editorial Review Board}

Diana Chandara
University of Minnesota-Twin Cities
Bao Diep
University of Minnesota-Twin Cities
Vanessa Sovanika Na
University of California San Diego
Khoi Nguyen
George Mason University
Hoa Nha Nguyen
Boston College
Linda Marie Pheng
University of Wisconsin-Madison
Latana Thaviseth
University of California Los Angeles
Melissa Vang
San Diego State University

\author{
Kassandra Chhay \\ University of Minnesota-Twin Cities \\ Annie BichLoan Duong \\ San Joaquin County Office of Education \\ Nielson Hul \\ Cornell University \\ Dung Minh Mao \\ University of Minnesota-Twin Cities \\ Thien-Huong Ninh \\ University of Southern California \\ Krissyvan Truong \\ Claremont Graduate University \\ Mai Vang \\ University of Massachusetts Boston \\ Thong Vang \\ University of Minnesota-Twin Cities
}

Soua Xiong

San Diego State University

Claremont Graduate University 